\title{
秋季関東部会講演 要旨
}

\author{
農業技術研究所（昭和46年11月13日） \\ Abstracts of Papers Presented at the Autumn Meeting of \\ Kanto Division, Tokyo, November 13, 1971
}

（1）大内 昭・富永時任 ペクチン質分解酵素に よる細胞壁物質の可溶化（5） 粘度法による可溶性多 糖質の重合度測定 Pectin lyase の作用により水溶 性となった細胞壁多糖質のらち, とくに重要と思われ る $0.2,0.3$ 扎よび $0.4 \mathrm{M}$ 画分の 平均重合度を粘度 法で求めて, 前報に和けるゲル沪過法の知見と比較検 討しよらとした。すなわち供試の各画分を $0.1 \mathrm{M}, \mathrm{pH}$ 6.0 の酢酸緩衝液に溶かしたのち, ガラスフィルター で沪過し，まず糖濃度を測定した。1.5-0.2\%（w/v） の範囲で段階的に糖濃度を変えた溶液 $6 \mathrm{ml}$ をオスト ワルド型粘度計に入れ， $25^{\circ} \mathrm{C} に$ に打る各溶液の粘度 を測定したのち，作図により糖濃度を 0 に外插して各 画分の極限粘度 [ク] を求めた。その結果 $0.2,0.3$ お よび $0.4 \mathrm{M}$ 画分の クはそれぞれ $0.24 ， 0.70$ 㧊よび 0.91 であった。一方, 標準物質の酸不溶性ペクチン 酸 Ia（重合度： $\mathrm{M}=26.96$ ) のそれは 0.196 であっ た。分子量が $10^{4}$ 程度までの鎖状高分子に拈けるク と $\mathrm{M}$ との関係は一般に， $\eta=\mathrm{K} \cdot \mathrm{M}(\mathrm{K}$ : 同族系列の高 分子について実験的に求められる定数) で示されるの で，上記の標準物質の知見からKの值は $7.23 \times 10^{-3}$ と計算された。このことから粘度法にもとづく各画分 の平均重合度はそれぞれ 33.0，96.3 执よび 125.2 と 計算され，前報の結論とよく一致する結果を得た。 (農技研)

（2） 米山伸吾* - 向 秀夫**. 陶山一雄** プリ ンスメロン斑点細菌病(仮称)について (1) 発生状況 数年前から, 茨城県下のプリンスメロンの葉に斑点性 の病害が多発し，早期枮れ上りの原因となっていた。 この病害はビニールトンネルの被覆を除去する 4 月下 旬- 5 月上旬から発生が認められる。葉では, はじめ に黄色の halo をともなった灰褐色の小斑点を生じ, これはしだい:融合して, 褐色不正形の大型病斑とな る。また葉縁部からも褐変が始まり, 病斑は葉の全面 に及ぶことがある。古くなった病斑はもろくなって破 れやすく，ときに穴があく，葉裏の葉脈には黄褐色の えそを生じ，しばしばき裂を生じ病勢が進むと，葉柄， 果梗等が褐変し枯死することもある。果実には緑色の halo を有する中央部が やや凸出した灰白色の微小病 斑が形成され, 重症被害株では果実の着果がいらじる しく阻害される。これらの罹病標本から病原菌を分離 したところ，いずれの標本からも細菌が分離され，分 離細菌はプリンスメロンに病原性を有し，再分離され た。上上のことから, 病名をプリンスメロン斑点細菌 病としたい。な拈果実にみられる微小斑点には, ウイ ルス性病斑执よび原因不明の斑点がありこれらにつ いては今後さらに検討を要する。

\section{（*茨城園試・**東京農大）}

（3）向 秀夫*・陶山一雄*·米山伸吾** プリン スメロン斑点細菌病について （2）病原細菌の細菌 学的性状 プリンスメロン斑点細菌病罹病葉执よび, 罹病果実から分離された病原細菌の細菌学的性状につ いて検討した。分離細菌はいずれも, プリンスメロ ン,キュウリ, ユウガオに強い病原性を示し, ヒョウ タン, カボチャには弱い病原性を示した。病原細菌 は, 桿状, グラム一, 芽胞一, 非抗酸性であった。 肉汁寒天で白色, のち淡黄色円形, ジャガイモ寒天で 白一淡黄色であった。ウシンスキー氏液にわずかに生 育, リトマス, メチレンブルーの還元十, オキシダー ゼ十, $\mathrm{NH}_{3}$ の産生十, ゼラチンの溶解は PM 16, 15, 13 菌が一, 他は十であった。インドールは PM 16, 15 菌だけが産生, $\mathrm{H}_{2} \mathrm{~S}$ の産生は $\mathrm{PM} 16$ だけ十, 硝酸塩の還元は PM 20,17, 16, 15, 14, 12 菌が十で, 他は一であった。牛乳は PM 20,17 菌が消化・凝 固, 酸十, PM 16, 15 菌が凝固, 酸十, 他菌株は消 化, 酸一であった。以上の結果から, 罹病葉から分離 した菌株は，P. lacrymans の 1 系統と考兄られる。 果実から分離した PM 16,15 菌株等については, 今 後さらに検討して種名を決定したい。

\section{（*東京農大・**茨城園試）}

（4）後藤正夫 イネ白葉枯病菌における集落型, ファージ感受性および病原力の相互関係 ファージを 使って選択的に分離したXanthomonas oryzaeのファー ジ抵抗菌には萊膜多糖質合成感を欠いた透明型集落 （T）を形成するものと，多糖質合成能を保持し，野生 
型と同じ不透明型集落（W）を形成するものがあり， 両者の比率は親株培養の新旧, 培地の種類等によって 異なった。保存培養中に解離する $\mathrm{T}$ 型集落もすべて ファージBPIに抵抗性を示し，ファージで選択分離し たものと同じであった。これら T型菌の大部分は病原 カがいちじるしく減退しているのに対し，W型抵抗菌 の病原力には強弱種々の段階があり, 一定の傾向は認 められなかった。病原力の強い野生型と病原力を汪と んど喪失したT型菌を種々の割合で混合接種すると, T型菌も野生型菌と共存する場合, 接種菌量に比例し て增殖することが確認された。しかし T 型菌は野生型 菌の病原力には何ら抑制作用を示さず, Pseudomonas solanacearum の場合とは異なった結果が得られた。 自然状態の田面水中で遊離 ファージの感染 $\left(10^{4}-10^{7} /\right.$ $\mathrm{m} l$ ) を受けた細菌集団を遠沈濃縮法によってイネ苗に 接種し, 発病後再分離して細菌集団中のファージ抵抗 菌の比率の変化を調べたが，イネ生育期間中，くり返 しファージ感染を受けても集団構成に顕著な変化は認 められなかった。（静岡大農）

（5）後藤正夫 - 忠内雄次 - 岡部德夫 Xanthomonas citri と腐生細菌の相互作用について X. citri の病斑内消長を腐生細菌との相互作用の面から究明す るためin vitroで実験を行なった。X. citri のストマ イ耐性菌之夏季に病斑内加りっとも高率に分離され る黄色細菌（Erwinia sp.）扣よび白色細菌（未同定） とを用い，培養温度とペプトン・しょ糖培地の成分濃 度を変えて調べた。 $30^{\circ} \mathrm{C}$ における世代時間は成分 濃度 $1.0,0.1,0.01 \%$ に対し X. citri 70, 108, 373 分, 黄色細菌 $31,30,35$ 分, 白色細菌 $25,29,36$ 分 であった。この場合腐生 細菌数が $10^{7}-10^{8} / \mathrm{ml}$ になる と培地の $\mathrm{pH}$ が徐々に低下しはじめ, 同時に $X$. citri の急激な減少が起こった。 $20^{\circ} \mathrm{C} に$ 打ける世代時間は それぞれ X. citri 144,189,400 分, 黄色細菌 51,62， 77 分, 白色細菌 59, 72,82 分で, 腐生菌の増殖が遅 延する結果, $X$. citri の增殖が持続した。 $30^{\circ} \mathrm{C}$ に和 ける $X$. citri の急激な減少は抗生物質や代謝産物の 有害作用, 培地の栄養枯渴等の理由では完全に説明で さなかった。 7 月に採取したナツミカン健全葉細胞間 汁液および接種後48時間経た感染葉細胞間汁液を用い て同じ実験を行なった結果, 前者では腐生細菌の増殖 が選択的に抑制されたのに対し，後者では，これがみ られず人工培地と同じ結果が得られた。(静岡大農)

（6）小泉銘冊 各種カンキツのかいよう病抵抗性 (1) 病斑の拡大傾向と病原細菌の消長 数種カンキ ツの新葉に $\mathrm{CP}_{1}$ 感受性菌を 単針付傷接種し（6月 1
日), 自然条件下に置き, 病斑面積 (LS), 病斑浮遊 液中でのファージ増殖程度 (PM), 病斑中の病原細菌 数 (NB) を約半月間隔で調べ，これらの相互関係を明 らかにした。PM は病斑から溢出する病原細菌数と平 行し, 病斑の伝染原としての重要度を示している。そ の結果，PMが大きいとその後の LS の拡大は急速で， 小さくなると緩慢になり，増殖が停止すると拡大も停 止した。すなわち PM は LS の拡大速度と平行した。 NB は LS の拡大速度が大きい期間は多いが，拡大を 停止したのち半月-1 カ月遅れて減少した。したが。 て LS の拡大傾向は伝染原から見たカンキッの抵抗性 を示す重要な指標と考えられる。これを 26 種のカン キツおよびその交配種について調べた結果，I：長期 間拡大を続けるもの（ネーブルなど），II：初期の拡 大は早いが比較的短期間で停止するもの（夏カンな ぞ), III : 拡大は緩慢であるが長期間続くもの（レモ ン), IV : 初期の拡大は緩慢で比較的短期間で 停止す るもの (ハッサクなど), $\mathrm{V}$ ：汇とんど拡大しないも の（ユズなど）の五つの基本型に分けられた。

(園試興津)

（7）稲葉忠興・梶原敏宏 暗処理罹病葉に形成さ れたキュウリべと病菌分生胞子の 2,3 の性質 ベと 病菌をキュウリ(品種・相模半白)に接種後, 暗処理す ると自然光線下においた場合(明処理)より病斑形成が 怙さえられ, 病斑組織中の菌系の生育もいちじるしく 悪くなることはすでに報告した。そこでさらに暗処理 した罹病葉に形成される胞子の性質を明処理した罹病 葉に形成される胞子の性質と比較して調べた。その結 果, 1) 病斑 $1 \mathrm{~cm}^{2}$ 当りに形成される胞子数は暗処理 罹病葉では $0.1-2.9 \times 10^{4}, 3.6-8.1 \times 10^{4}$ で，明処理

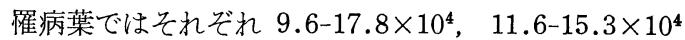
であった。2）暗処理罹病葉には 細胞質のない胞子が 多数形成され 総胞子数の $28-56 \%$ であったが，明処 理罹病葉では 16-30\% であった。3) 暗処理羅病葉に 形成された胞子の発芽率は 19-57\% と低くかったが， 明処理罹病葉では 75-89\% であった。4）暗処理罹病 葉に形成された胞子の病原性は, 明処理罪病葉に形成 された胞子よりやや高い傾向を示した。（農技研）

（8） 大森 薰 カンキツ黑点病菌の胞子形成に及 ぼす光の影響 供試菌として Ser-1, Ser-3, Ci1-2 の 3 菌株を用い, 培地として V-8 ジュース寒天, 乾 アンズ寒天, 乾アンズ・ $\mathrm{V}-8$ ジュース寒天, ジャガイ モ寒天を用いた。培養温度 $28^{\circ} \mathrm{C}$ のとき暗黒ではすべ ての培地で 3 菌株ともに胞子形成はほとんど認められ なかったが, 白色螢光灯をシャーレ上ぶた $30 \mathrm{~cm}$ の 
ところから照射するとかなりの胞子形成が認められ た。各種螢光灯, すなわち純赤色, 純黄色, 純緑色, 純青色, ブラックライトブルー螢光灯（BLB）を照射 したところ，BLB 照射区で 3 菌株ともにすべての培 地で多くの胞子形成が認められた。BLB 照射による 胞子形成の増大は培養温度 $24^{\circ} \mathrm{C}$ のとき培養 6 日から 7 日めごろにもっともいちじるしかった。 $24^{\circ} \mathrm{C} て ゙ 5$ 日間暗黒で培養したのち, 各種ガラスフィルターを用 いて有効波長を検討したところ， $350 \mathrm{~m} \mu$ 近辺の光照 射で 3 菌株ともに胞子形成が認められた。 $24^{\circ} \mathrm{C}$ で 5 月間暗黒で培養したのち, BLB 照射下各種温度で 5 日間培養したところ, 菌株により差はあるが $20^{\circ} \mathrm{C}$ 以 下では大半 $\alpha$ 型胞子を形成し, $30^{\circ} \mathrm{C}$ 以上では $\beta$ 型 胞子を多く形成した。両型胞子を夏ミカン苗に接種し たところ， $\alpha$ 型胞子だけに病原性が認められた。

(日本化薬上尾研)

（9）鈴木穂積 いもち菌胞子懸濁液の乾燥による 発芽率の変動と温度との関係 胞子の発芽には水滴が 必要であり, 発芽前に水滴が乾燥すると再び懸濁して も発芽率はいちじるしく低下する。懸濁および乾燥時 の温度による発芽率の影響を知ろうと実験した。温度 は $5,12,15,20,25,28,31^{\circ} \mathrm{C}$ の 7 段階で, 胞子䀣濁 と乾燥時間は各 60 分ずつとし, 発芽調査は所定の処 理を終ってから $28^{\circ} \mathrm{C} 10$ 時間後に行なった。䯚濁から 乾燥時をとおして温度ごとに処理したところ, 発芽率 は $5^{\circ} \mathrm{C}$ で影響されないが， $12^{\circ} \mathrm{C}$ 以上高温ほどいちじ るしく低下した。懸濁だけを各温度で処理し，乾燥は すべて $28^{\circ} \mathrm{C}$ で行なったところ, 全温度でいちじるし い低下がみられた。懸濁時に $5^{\circ} \mathrm{C}$ と $25^{\circ} \mathrm{C}$ に保った区 を設け, 各区の乾燥時に温度ごとに処理したところ， 懸濁時 $5^{\circ} \mathrm{C}$ 区では乾燥時 $5^{\circ} \mathrm{C}$ で影響はなく， $12^{\circ} \mathrm{C}$ 以上では温度の上昇とともに低下が みられた。 $25^{\circ} \mathrm{C}$ 区では $5^{\circ} \mathrm{C}$ でも半減し, 温度上昇にともないいちじる しく低下した。懸濁と乾燥時を $5^{\circ} \mathrm{C}$ と $28^{\circ} \mathrm{C}$ に保。 た区を設け，懸濁液が乾燥するまでの 10 分間だけを 温度ごとに処理したところ， $5^{\circ} \mathrm{C}$ 区では全温度で低下 率は低く, 温度間差も少なかったが, $28^{\circ} \mathrm{C}$ 区では全温 度でいちじるしく低下した。以上から, 懸濁後の乾燥 による発芽率の低下は発芽可能温度範囲内で抗こり， 高温ほど顕著であることがわかった。（北陸農試）

（10）羽柴輝良・茂木静夫 イネ紋枯病菌菌核の age と発芽 菌核形成から発芽能力消失まで, 菌核の 発芽率の変動を調査し, 自然菌核（围場採集）と培盖 菌核（PDA 培地）のちがいを検討した。各供試菌核 をとれぞれ 無殺菌と表面殺菌（昇秀 1,000 倍，1分
間）処理, 水洗後, $2 \%$ 素寒天, $25^{\circ} \mathrm{C}$ で発芽を行なっ た。形成初期にみられる白色状の自然菌核は $90 \%$ 以 上の高発芽率で, 褐変化するにつれて $60 \%$ 前後に減 少し, 融雪時（約 300 日） まで变化しない。融雪と同 時に発芽率が急速に減少する。殺菌菌核は白色時 約 $70 \%$ の発芽率であるが，褐変とともに急速に発芽率 が減少し, 菌核形成後 20-30 日ごろ, 菌核が沈下か ら浮上状態に 移行する時期には 10-20\% となり, 約 3 力月間低発芽状態を保ったのち, 発芽率の上昇が認 められる。以後は無殺菌菌核と同様な経過をたどる が，発芽率は約 $10 \%$ ほど低い。一方培養菌核 $\left(25^{\circ} \mathrm{C}\right.$, $100 \%$ 湿度保存）は 250 日まで 100\% の発芽率を示 すが，以後急速に減少する。殺菌培盖菌核では 40 日 めから急速に減少し，無殺菌との差が 40-50\% にな り, 殺菌自然菌核でみられた発芽率の上昇はない。以 上から, 自然菌核は培養菌核より発芽能力を長く保持 できる性質をもつと考えられる。（北陸農試）

(11) 高屋茂雄 Cylindrocladium scoparium 菌に見られる生育異状の伝染条件 (2) 正常 菌と接触させた異状菌そうの異状程度および接触時間 と伝染力 本菌の生育異状にはさまざまの程度がある が, 生育異状菌と正常菌を混合して接種し, 伝染を起 こさせる場合, 前者の異状程度と伝染性の間にどのよ らな関係があるかを検討した。その結果, 菌そらの直 径が 20-40 mm で生育が停止してしまう程度の生育 異状菌の分生胞子または菌系と, 正常菌の分生胞子を 混合接種すると, 発育してくる菌とうにはもっとも強 く生育異状が現われた。菌そうの直径が 10-20 mm 程度の小さいらちに生育が停止してしまう異状菌そう の伝染力は，か觉って弱かった 1 個の分生胞子から発 芽後，28-48 時間を経た正常菌の小菌そうに，正常菌 そらより小さく，また，それ自体からは菌系が伸育し ない異状菌糸ブロックを所定時間接触させ，伝染に必 要な両菌の接触時間を調査した。その結果，接触時間 3 時間では伝染は生じなかったが, 6-9 時間以上で は，ほとんどの接触処理によって伝染が生じた。しか し，接触させる時間をそれ以上延長しても，発育して くる菌そうの異状程度にはほとんど差異は認められな かった。（茶試）

（12）清沢茂久 真性抵抗性と畨場抵抗性を組合せ た場合の品種の寿命に関する考察 真性抵抗性と圈場 抵抗性を組合せた場合の品種の安定性あるいは寿命に ついてシミュレーションにより検討を行なった。年内 の增殖曲線が $y=y_{0} e^{r(t-t 2 / 2 T)}$ により表わされるとき, その品種の年間增殖曲線のこう配は, 品種の䀯場抵抗 
性に依存し，その水準は真性抵抗性に依存する直線に なる。年内の増殖曲線が $y=\frac{Y^{\prime}}{1+k e^{-r t}}$ で表わされる ときには，真性抵抗性の利用価值はほとんどない。両 式を組合せた $y=\frac{Y^{\prime}}{1+k e^{-r\left(t-t^{2} / 2 T\right)}}$ で年内の増殖曲線 が表わされるとき, 初め固場抵抗性に依存寸るこら配 をもち真性抵抗性遺伝子の種類によって違ら水準をも つ扣互に平行な直線を示すが，最後には一定水準に漸 近する年間増殖曲線を示す。第 3 の式で見られた曲線 が現在のところもっとも実際にあらように思われる。 結果は, その品種の安定性や寿命は年内の病原菌の増 殖様式(曲線)がどのような性質を示すかにより異なる ことを示す。（農技研）

（13）松尾卓見* ·松田 明** · 尾崎克己** · 加藤 喜重郎*** ゴボウ萎ちょう病の病原菌 Fusarium oxysporum f. sp. arctii n. f. ゴボウ萎ちょう 病は松田らによって命名されたが，松尾・加藤は愛知 県産のものについて検討中であった。茨城県産・愛知 県産のものは同一病原菌によって扣こることが判明し た。本病原菌は明らかに Fusarium oxysporum 菌で ありゴボウ実生に対しいちじるしく強い病原性を示 す。ゴボウ品種の滰野川・柳川理想・大浦太・常盤赤 茎大長・渡辺早生・道産滝野川はいずれも $90 \%$ 以上 の枯死率を示した。ゴボウ所属のキク科に関係ある Fusarium axysporum の分化型（f. sp.）に f. sp. callistephi (アスター菌) と f. sp. lactucae (チシャ 菌）があるが，これらはゴボウに対し全然病原性を示 さない。またゴボウ菌は，アスター，チシャ，スイ カ, メロン, キュウリ，ユウガオ，ゴマ，トマト，ナ ス, ホウレンソウ, アスパラガス, アマ, ダイズ, イ ンゲン, ササゲ, エンドウ, カンラン, ダイコン, タ マネギ，ワタなどに対し全然病原性を示さない。した がって新しい分化型と認め，Fusarium oxysporum Schl. f. sp. arctii Matuo, Matsuda et Kato $と$ 命名したいと思ら。

$(*$ 信州大繊維 $-* *$ 茨域農試・***愛知農総試園芸研)

（14）横沢菱三*・生越 明**. 尾沢 賢***.水倉 薰 ・酒井隆大郎** ・ ハクサイ根くびれ病（俗称ポッ クリ病) について 昭和 40 年ごろから長野県木曾郡 に発生したハクサイの俗称ポックリ病は年を追うごと に激しくなり，木祖村では 44 年には栽培面積の約 $30 \%$ に発生した。その典型的な症状に拈いては胚軸 部がくびれ，収穫期ごろにはとの部分から下の根部は 乾腐状となり，かららじて上部から発生した不定根に よって生存している。風や薬刘散布時の圧力で被害部
から折れて地上部が飛ばされることが多い。このため 生育遅延をひき抗こし，はなはだしいとさは枯死す る。この症状はダイコンでも見られる。病植物および 病土から病原菌の検出を試夕たところ，Aphonomyces raphani Kendrick が高頻度に分離された。この菌に ついてその宿主範囲を調べたが，調査したすべてのア ブラナ科植物に子苗立枯をひき抏こし，またこの菌の 接種土壌にハクサイを播種し，栽培したところ，明ら かな根くびれ症状を示した。A. raphani による病害 はルタバガ根くびれ病が北海道で報告されて扣り，本 病は同様にハクサイ根くびれ病と呼びたい。

（*明大農・**農技研・***長野園試・ †木貥防除所）

（15）尾沢 賢*·水倉 薫**. 横沢菱三** · 生越 明†，酒井隆太郎†長野県に発生したハクサイ根くび れ病の防除について 筆者らは数種の土壤殺菌剂を供 試し, 連年ハクサイ, キャベッを連作して, 本病が発生 した戒場で試験を行なった。その結果を薬剤別に要約 すると以下のと扣りである。PCNB $20 \%$ 粉剤 (30 kg/ $10 \mathrm{a})$, イソキサゾール $4 \%$ 粉剂 $(20 \mathrm{~kg} / 10 \mathrm{a})$ は播種 畦上処理では効果は認められない。DAPA 4\%粉剂 (30-40 kg/10a) の播種畘上処理は有効であるが，実用 的にはさらに高い防除効果が望まれる。クロルピクリ ン剤 $(30 \mathrm{~cm}$ 間隔, 深さ $10 \mathrm{~cm}, 3 \mathrm{cc}$ ) 処理は DAPA 粉剤と同等かやや劣った。臭化メチル剤 $(25 \mathrm{~kg} / 10 \mathrm{a})$ 全面処理は高い防除効果が認められ，無処理区の発病 株率 $71.0 \%$ に対し 10.5\%であった。な拈本剤は防除 効果のほか， ハクサイの草勢を良くし，かつ殺草効果 も認められた。本剤の処理作業はクロルピクリン剂よ り容易で処理期間も短く普及性が高いと考えられる。 な扣耕種的防除法として, 消毒苗床に一定期間育成し たハクサイ子苗を本國に移植することによって，本病 を相当に回避することが観察されたが，臭化メチル剂 による土壤消毒と子苗の移植を併用することによって 本病の防除効果をさらに高めることが考えられる。

(*長野園試・**木篔防除所・***明大農・†農技研)

（16）夏目孝男 · 小塚宅右工門. 井上好之利Plantvax, Vitavax のキク白さび病防除に対する作用性の 検討 1,4-Oxathiin 系化合物としての Vitavax (V. V) 和よび Plantvax(P.V) についてキクの白さび病 を対象に作用性を検討した。1）散布効力：V.V, P.V の 1,000 倍液を茎葉に散布し 接種源中に入れて効力 を検討した結果, 雨剤とも有効でとくに P.V は 1 力 月以上発病を抑制した。2）小生子形成阻止力：発病 葉を直径 $3 \mathrm{~mm}$ のパンチで打拔いた葉片 (胞子堆 2-3 個)を P.V, V.V の 1,000 倍液中に浸漬し，小生 
子形成の有無について検討した結果，両剤で処理した 胞子堆からは小生子の形成がまったく認められなかっ た。3）小生子の発芽阻止力：V.V, P.V の 1,000, 2,000 倍液を所定量散布したスライド上に小生子を落 し発芽阻止力を検討した結果，顕著な効力が認められ た。4）土壤灌注による防除効力：素焼鉢に 栽培中の キクを用い, P.V, V.V を病菌の 接種前灌注 と接種 後灌注とに分け検討した結果，とくに P.V の効力は 顕著で接種前に鉢当り $5 \mathrm{mg}$ (製品量) の灌注量で 1 カ月近くの効力が認められた。また治療的にも有効で 冬胞子堆の形成をかなり抑制した。

\section{（全購連農技センター）}

（17）米山伸吾*. 菅田重雄**. 飯島 勉*** キク 白さび病の薬剤防除 キクの白さび病に対する 2,3 の 薬剂による防除試験の結果を報告する。ビニールハウ ス内ポットマム品種で, ピオマイ剤 500 倍液の 1 週間 2 回散布が, アンバム剤に比してその効果が高かった。 その後オキシカルボキシン,カルボキシン剤の 1,500 3,000 倍液を散布したところ，すでに形成された冬胞 子堆周辺が黒褐色に, 次いで冬胞子堆が黒-茶褐色に 変色し，そして新たな発病をも括さえた。散布間隔で はオキシカルボキシン剤 2,000 倍液の場合, 14 日拉き でも効果がみられたが，7日扣きに比してかなり劣っ た。つぎに両風 1,000-8,000 倍液の土壤灌注では, 2 日めごろから冬胞子堆は散布と同様に変色し, オキ シカルボキシン剂で 4,000 倍, カルボキシン剂では 2,000 倍まで, それが顕著にみられた。オキシカルボ キシン剂 2,000 倍液の $1,2,3$ 週間扣さ灌注処理で は，いずれもまったく発病せず顕著な効果がみられ， また径 $15 \mathrm{~cm}$ の鉢に同液 $100,50 \mathrm{ml}$ を灌注しても 同等の効果が認められた。な扎両剤の 1,000-1,500 倍 散布では, 葉の先端-葉辺部が黒, 褐変し, 3,000 倍 液では品種によりそれを生じ, オキシカルボキシン剤 4,000 , カルボキシン剂 2,000 倍液の灌注では, 新葉 の葉辺が黒変した。

（*茨城園試・**東京農試江戸川・***東京農試）

（18）御園生 尹・深津量栄 ナシ赤星病に対する triarimol 剤の効果 本病菌の各胞子世代に 対する各 種薬剤の 効果を検討しているらちに triarimo1 剂が ナシ葉上で従来みられなかったほどの特異な効果を示 すことを認めた。すなわち, 冬胞子堆に対する散布で は小生子形成抑制効果はなく，また小生子および銹胞 子に対する発芽抑制効果も低いのに, ナシ葉での小生 子接種後の経過日数と散布効果との関係は明瞭で, 接 種 3 日後の散布でも典型的な病斑を形成することな
く，黄色-紫色の変色斑にとどまり，また精子殼の形 成も完全に抑制した。さらに精子款数 8 個内外の初期 病斑（接種 10 日後）に対する 1 回散布でも高い効果 を示し, 病斑のその後の拡大抑制（病斑直径では無散 布区の約 1/4), 精子殼の 新形成の抑制 (約 1/3), 蜜 の溢出が遅延されるほか, 病斑の肥厚や銹子腔の形成 の抑制（数少なく短小で銹胞子量極少）などがみられ た。しかし，形成した銹胞子の発芽率は無散布区の々 れと変わるところはなかった。さらに後期散布の検討 の要は残されてはいるが，以上からみるとナシ葉上に 技㺭る感染の数日後散布でもかなりの治療効果が認め られるので, 従来重視されていた中間寄主上での対策 の軽減を可能にするものと期待される。(千葉農試)

\section{（19）土崎常男 インゲンから検出された peanut} stunt virus（PSV）について 1970 年福島県農試圃 場で採集したインゲンのモザイク病株数株を調べたと ころ, bean common mosaic virus, bean yellow mosaic virus, cucumber mosaic virus (CMV), および末知ウイルスの 4 種ウイルスが種々の組合せで 混合感染していた。未知ウイルスをクロロホルム処 理, 分画遠心後しょ糖密度こう配遠心で純化し, 電顕 観察すると径 25-30 nm の球形粒子が認められた。未 知ウイルスは容易に汁液伝染するほか, モモアカアブ ラムシママメアブラムシで非永続的な伝染をした。寄 主範囲は広く, インゲンで葉にモザイク, 奇形, 株の 萎縮, ピーナッツで葉にモザイクを示したほか, 多く のマメ科, ナス科の植物, およびアカザ科, ゴマ科, ツルナ科, ヒユ科の植物にも感染した。粗汁液中のウ イルスの不活化限界は耐熱性 $55-60^{\circ} \mathrm{C}$ (10 分); 耐保 存性 5-10 日 $\left(15^{\circ} \mathrm{C}\right)$, 耐希釈性 1,000-10,000 倍で あった。このウイルスの抗血清は broad bean wilt virus と反応せず，また本ウイルスは CMV-Y 抗血 清とも反応しないが，USA の PSV 抗血清と寒天内 拡散法で明らかな反応を示した。以上の諸性質は USA で報告された PSV とよく一致し, 本ウイルス を PSV と同定した。PSV が USA 以外で検出され たのはこれが最初である。（植物ウイルス研）

（20）大島信行*. 荻原佐太郎*.青木宏史** TMV 抵抗性トマトから分離されたトマト系 TMVについて 1971 年千葉県農試で試作中の TMV 抵抗性トマト (長野, RXS) に多くのモザイク病が発生した。これ らのトマトは 3,4 年前から試作されたが 1970 年ご ろからモザイク病がしだいに多くなった。これらのモ ザイク病株とハウスホマレのモザイク病株から TMV を分離して性質を調べた。抵抗性トマトのウイルス系 
統 No. 2 および 4, 八ウスホマレの No. 3 はタバコ, インゲン括よび感受性トマト上の病徴からは区別が困 難で普通のトマト系 TMVの症状を示した。しかし前 記抵抗性トマトの幼苗に接種すると No. 2 と 4 はた だちに発病させ, No. 3 接種株は発病が遅れ, 病徵も 葉面に淡緑の小病斑を散在させた軽いものであった。 また高い抵抗性を示すトマトの別系統 (TVR-1) は いずれの系統に対しても接種葉に褐色の斑点を生じ, 一部の株は頂端えそを示し，のちに伸長した側枝には モザイク斑紋を生じた。またモザイク病の感受性トマ トの枝を接木された TVR-1 も頂端えそを生じた。弱 毒トマト系 TMV, L 11 の黄斑系 L 11 Y は抵抗性 トマト（長野, RXS）を通すとこれらのトマトに感染 しやすい黄斑系統になった。以上の観察と実験の結果 から感受性トマトのウイルスも抵抗性トマトを通すと これらに対する病原性を獲得するものと考学られる。

(*植物ウイルス研・**千葉農試)

（21） 岩木満朗 スイセンから分離されたウイルス 第 6 報 Arabis mosaic virus について 著者はわが 国のスイセンから今まで 6 種のウイルスが分離される ことを報告したが，今回スイセン（大杯）から arabis mosaic virus (AMV) が分離されたので，これにつ いて報告する。このウイルスは寄生性が広く, 14 科 43 種の植物に接種したところ, 12 科 34 種に感染が 認められた。モモアカアブラムシによっては伝搬され なかった。Xiphinema 線虫を含むクワ根部周辺土潩 に本ウイルスに罹病したペチュニアを植え，2週間後 にその病株を抜きとり，健全ペチュニアを植え付けた ところ, 土潩伝染が認められた。単離 Xiphinemaによ る伝搬試験は現在実験中である。耐熱性は $55-60^{\circ} \mathrm{C}$, 耐保存性は 3-4 週間 $\left(20^{\circ} \mathrm{C}\right)$ 。 ウイルス 粒子は径約 $25 \mathrm{~m} \mu$ の球形で, 部分純化ウイルスを用いて作製し た抗血清は沈降反応混合法で 1,024 倍の力価を示し た。 4 種 NEPO ウイルス (AMV, tobacc ringspot virus, tomato black ring virus, tomato ringspot virus）の抗血清を用いて, 本ウイルスとの血清学的 類縁関係を寒天ゲル拡散法により認べたところ, AMV の抗血清とだけ特異的な反応帯を生じた。以上の結果 から本ウイルスを arabis mosaic virus と同定し, 和名をアラビス・モザイク・ウイルスとした。

(植物ウイルス研)

（22）久保 進*.大橋雄司**・都丸敬一* タバコ モザイクウイルスの高感受性新局部病斑寄主, Xanthi NN タバコについて Xanthi タバコ(Nicotiana tabacum L.) に N. glutinosa の N 因子を付与する
目的で Vamorr 48 を交配した。その後代について Xanthi との戻し交配と TMV に対する反応の検定 を行ない, TMV に高い感受性を示す局部病斑寄主 を固定系として選抜し，Xanthi NNを命名した。 Xanthi NN は生育経過, および草型, 葉型などの形 態的特性がいずれも Xanthi と差異がなかった。気温 23-28 ${ }^{\circ} \mathrm{C}$ のガラス室で育てたは種後 50-60日の Xanthi NNを $N$. glutinosa 拈よび既存の N 因子を有 するタバコとの TMV に対する感受性を, 局部病斑 数によって比較した結果, $0.02-0.05 \mu \mathrm{g} / \mathrm{m} l$ の TMV を塗抹接種した Xanthi NN 葉の単位面積当りの病 斑数は N. glutinosa の約 12 倍 (9.2-17.5), Holmes' Samsun, Samsun NN, および Xanthi-nc の 4-7 倍であった。Xanthi NN は TMV-RNA に対し ても高い感受性を示した。Xanthi NN の展開葉で得 られた TMV の infectivity-dilution curve（両対 数表示) は, TMV 濃度が $0.003-0.05 \mu \mathrm{g} / \mathrm{m} l$ の範 囲で直線的であった。Xanthi NN は TMV 执よび TMV-RNA の高感度の定量寄主として有用である。

\section{（*秦野たばこ試・**宇都宮たばこ試）}

（23）大橋祐子.下村 徹 Local lesion の形成亡 透過性の変化 TMV によってN. glutinosa 葉に lesion が形成されるとき, 感染部が褐変する前に, この部で組織の凹入がきわめて明らかになる。過湿状 態では，褐変がまだはっきりしない時期にすでに感染 部に水滴が滲出する。また lesion 形成葉の浮遊液の 電気伝導度を測定すると, この葉には電解質の“漏 れ”をひき扤こす変化が起こっていることが明らかな ので (本年の大会で報告)，われわ机 lesion が形 成される部分で細胞膜がいずれかの変化を受けて崩壊 し，細胞内液の “漏れ”が起こり膨圧が低下するので はないかと考えている。今回は TMV 接種後 $30^{\circ} \mathrm{C}$ に 2 日保ち全身感染させた $N$. glutinosa 葉に葉柄から ${ }^{32} \mathrm{P}$-りん酸を吸収させ，短時間の冷，熱処理を加えた 場合の local lesion 形成と放射能の“漏れ”との関 係を調べたので報告する。“漏れ”は処理葉を経時的 に一定量の水で洗い，洗液の放射能を測定することに よって調べた。各処理による lesion 形成に先だって 組織の変化が 肉眼で観察されるが，“漏れ”はそれと 同時かやや先だって始まり, lesion の完成前に減少す る。ここでは洗液中の ${ }^{32} \mathrm{P}$ はほとんど有機りんに変 化しているので, この現象は単に葉組織に吸着した ${ }^{3} \mathrm{P}$-りん酸が洗液中に遊離したためのものではなく, 細胞内液の滲的に由来したものと考えられる。

（植物ウイルス研） 
（24）細川大二郎・福田顈穂 - 森 寛一 螢光抗体 法によるアブラムシ体内の TMV の検出 電顕観察な ぞにより，TMV 粒子がアブラムシの胃にとりこまれ ることは 2,3 報告されているが，その後のアブラム シ体内でのウイルスの移行, 消長やその病原性につい てはまだ明らかではない。これらの点を解明するた め, TMV 罹病タバコを吸汁させたモモアカアブラム シの体内报よび肛門からの排泄物中の TMV の分布 を螢光抗体法拈よび電顕観察により検討した。吸汁後 アブラムシは冷アセトンで固定し, 低温パラフィン法 により連続切片とし，螢光標識抗体で染色，鏡 検し た。その結果, 吸汁 1 日後に第 1 胃内腔の一部に弱い 特異螢光が認められ，吸汁時間が長くなるにしたがっ て,この特異螢光は強くなり，胃内部全体に広がる が，胃壁外への移行は認められなかった。そして 5 日 間以上吸汁させたアブラムシでは第 1 胃内腔の強い特 異螢光のほか、, 第 2 胃先端部に弱い特異螢光が認め られるものがあるが，それより後部の消化管拈よびそ の他の体内器官には特異䖝光は認められなかった。次 に病植物を吸汁中のアブラムシの肛門からの排泄液を スライドグラス上に採集し，グルチノザへの接種拈よ びネガティブ染色による電顕観察を行なったが，これ らからはウイルスが検出された。（東京農工大農）

（25）新海 昭 ヒメトビウンカによるイネ縞葉 枯ウイルス，ムギ北地モザイクウイルスの獲得媒介に 及ぼす虫令の影響およびナカノウンカのムギ北地モザ イクウイルスの媒介能力 無毒ヒメトビウンカに病株 を2 日吸汁させてウイルスの獲得媒介虫率をみた。

$\mathrm{RSV}$ の獲得媒介虫率は 1 令虫 $10 \%$ 以下, 3 令虫 10 数\%，5 令虫約 $30 \%$ ，成虫約 $80 \%$ であった。成虫 の場合, 獲得吸汁数時間で $30 \%$ 近くが媒介し， 1 日 吸汁では $60 \%$ に達した。成虫の老若による獲得媒介 虫率には注とんど差がなかった。 RSV 獲得成虫は獲 得吸汁開始後 10 日あるいはそれ以上を経て媒介を始 める個体が多かった。な扮，夏秋期の実験ではいつも 成虫の早死が多かった。先に筆者 (1958, ほか) は 5 令虫. 成虫の獲得媒介虫率が低いことを記したが，こ れは早死が括こりやすい夏秋期の実験に基づくもので あり，その媒介率の低下は供試個体の早死（媒介前の 死）のためと考兄られる。NCMV の獲得媒介虫率は 1 令虫 $80 \%$ 以上，3 令虫約 $40 \%, 5$ 令虫 20 数 $\%$, 成虫約 $20 \%$ であった。以上の結果から吸汁獲得した $\mathrm{RSV}$ は成虫增殖性, NCMV は幼虫增殖性之考兄ら れる。な怙, ナカノウンカ, ヒメトビウンカの 1,2 令虫に NCMV の病株を 15 日獲得吸汁させた場合,
その獲得媒介虫率はナカノウンカ $26 \%$ ，ヒメトビウ ンカ $93 \%$ であった。（植物ウイルス研）

（26）長井雄治・深津量栄 栽培管理にともなうス イカの CGMMV の伝染 CGMMV スイカ系による スイカのモザイク葉をすりつぶし，蒸留水による希釈 系列をつくり，これを常法によりキュウリ苗に接種し た。1 $0^{6}$ 倍以下の低濃度になると発病率が低下し，潜 伏期間が長びく傾向がみられたが，107倍をで発病可 能であった。また， 10 倍希釈液の 1 滴を 1 葉期の二 ウガオの子葉上に滴下したところ，無傷のままでは発 病することはなかったが，1-7 日後に滴下部位を穿針 すると約 30 日後に低率ながら発病が認められた。次 に, 病汁液の付着したカミソリの刃によるユウガオ茎 への切り傷扣よび接ぎ木用竹べらによる刺し傷によっ ても容易に発病が認められ，接ぎ木のさいにかなり高 率の伝染が扣きる可能性が確認された。さらに, 病株 の花粉を交配したところ，きわめて軽く行なったので はほとんど感染しないようであったが，慣行のこすり つけ交配法では約半数が発病した。一方，スイ力戋場 で開花初期ころに 15-20\% の株に接種して散発状態 に放置して打くと，40-50 日後の収穫期には全株にま ん延することが確かめられた。しかし，ウリバェとア ブラムシによる伝染の可能性は実験の結果から否定さ れた。（千葉農試）

（27）杤原比呂志 抗血清を利用してのカーネー ション汁液が持つウイルス感染阻止作用の防止 カー ネーション汁液には強い感染阻止作用があるため感染 ウイルスの種類を同定する際の障害となる。抗血清を 利用してこの阻止作用を軽減することを試みた。カー ネーション凍結葉をクロロホルムー硫安による塩析ーア セトン-DEAE セルローズ等で処理し半精製の感染 阻止物質を得た。この標品を抗原として抗血清を作製 した。Tomato ringspot virus 感染カーネーション にりん酸緩衝液（P.B.）を加えて磨砕した汁液のこ すりつけ接種ではキュウリにほとんど感染が起こらな いが，抗血清を添加した P.B. を加元て磨砕し， $30^{\circ}$ C，30-120 分処理した汁液では 50-100\% の株が発病 した。抗血清を添加しても磨碎直後の接種では感染率 が低いことから, この感染性の回復は抗原抗体反応に よるものと考穴ている。TMV にカーネーション，ビ ジョナデシコ, およびC. amaranticolorのいずれの汁液 を加光ても N. glutinosa の local lesion 数をいちじる しく阻止するが，この混液に上記の抗血清を添加する とカーネーション区で感染性が大きく回復し, ビジョ ナデシコ区でもかなりの回復がみられるが，C．ama- 
ranticolor 区では回復しない。C. amaranticolor を用 いてコーラル種から carnation mottle virus の検 出を試みたが，磨砕の際に抗血清を添加することで検 出率を高めることができた。（植物ウイルス研）

（28）小金沢碩城・土居養二・與良 清 カブモザ イクウイルスと cytoplasmic inclusion の分別純化

PVY 群ウイルス感染でウイルスの粒子とともに産 生する cytoplasmic inclusion (CI) の本体を解明す るため, この両者を多産するカブモザイクウイルス感 染コマツナ葉を供試し，分別純化を試みた。まず 2 容の $0.5 \mathrm{M}$ citrate buffer ( $\mathrm{pH} 7.5$ ), $1 \mathrm{M}$ urea, $0.01 \mathrm{M} \mathrm{Na}_{2} \mathrm{SO}_{3}$ 混液中で葉を磨砕後, Triton X-100 を $5 \%$ まで加え，60 分振とう後 $15,000 \mathrm{rpm}, 20$ 分 遠心し，その pelletを水に溶かし $50 \%$ しょ糖液に重
ね 3,000 rpm，10 分遠心し上清をとる。この分画遠 心を再度行なったのち pellet を分散し，含まれるCI を 40-80\%しょ糖密度こう配遠心し純化した。ウイル ス粒子は最初の高速遠心上清を $30,000 \mathrm{rpm}, 120$ 分遠 心し, pelletに集め，これを上記 buffer, 0.5 Murea 混液に溶かし分画遠心としょ糖密度こう配（20-50\%） 遠心して純化した。純化 CI は電顕下でシート状構造 物がほとんどであるが，少量のウイルス粒子も含まれ さらに精製の余地がある。この CI とウイルス粒子の たんぱくを $8 \mathrm{M}$ urea を含む Reisfeld らの方法で acrylamide gel 電気泳動を行ならと異なった位置に 泳動された。以上の結果と既往の形態的知見を総合す るとウイルスコートと CI のたんぱくは理化学的性状 の異なる別種たんぱくと考えられる。（東大農）

\title{
北 海 道 部 会 講 演 要 旨
}

北海道農業試験場（昭和46年11月20日）

\begin{abstract}
Papers Presented at the Meeting of the Hokkaido
Division, Sapporo, November 20, 1971
\end{abstract}

（1）青田盾彦・真野 豊 インゲンかさ枯病菌に 寄生するファージの検出（予報） ほ場のインゲン(大 正金時) に発病したかさ枯病 (Pseudomonas phaseolicola）の罹病葉拉よび罹病莢の病斑部ならびに罹病 株の根圈土袞を採集して, P. phaseolicola 菌を供試菌 としてファージの分離を試みた結果，いずれからも溶 菌斑 (ファージ) が検出された。これらファージの寄 生性について, Erwinia 属 1, Corynebacterium 属 1, Xanthomonas 属 5, Pseudomonas 属 34 種 46菌株, 計 4 属 53 菌株を用いて検討した結果，上記の 3 部位 から検出されたファージは P. phaseolicola の 4 菌株 （race 1，race 2 など）だけに寄生が認められ，特異 性の高いことが明らかとなった。なお，今後本ファー ジの他菌種拉よび P. phaseolicola . 菌株に対する寄生 性をはじめ生理的性質など検討したい。

（道立北見農試）

（2）宮島邦之 イネ葉鞘褐变病菌の抗血清につい てイネ葉鞘裼変病病原細菌 6801 菌株をブイヨン寒 天培地で $28^{\circ} \mathrm{C}, 20$ 時間培養して供試した。これを遠 心洗浄後, 生理的食塩水で約 $10^{7} / \mathrm{m} l$ の細菌け几濁液 をつくり，家鬼の皮下执よび静脈に 6 回注射して，力
洒 25,600 の抗血清を得た。この抗血清の 100 倍希勫 液で試験管内凝集反応を行なったところ，北海道内各 地から集収保存した病原細菌 252 菌株すべてと反応 乙, 随伴菌 27 菌株, Pseudomonas 属 (19 種), 他属 （5 属 9 種）之は反応しなかった。また，ハンガリー から輸入した P. oryzicola は反応しなかった。この抗 血清の國場診断への応用を検討した結果, 病斑部の磨 粋液は試験管内反応で㠜集反応し，健全部は反応しな かった。以上の結果, 用いたイネ葉鞘褐変病菌菌株の 抗血清は北海道内の本病原細菌に高い特異性があり, また本病の診断に有効と思われる。（道立上川農試）

(3) 成田武四 Ovularia 菌によるチモシー, レッドトップなどイネ科牧草の白かび病 チモシーの 葉に, Heterosporium phlei による斑点病病斑に似る がやや大形，紡錘形，赤褐色で，周縁は紫色となるこ となく病斑周囲に黄色暈が目だつ斑点が最近多発し， またケンタッキーブルーグラスの葉に, Helminthosporium vagans に上る褐玟病の紡錘形病斑似似るが 少形で，内部退色することなく周囲に黄色暈がある斑 点がよく発生する。両草種のこれらの病斑からは無色 の分生胞子拉よび子梗が検出される。胞子ば気孔から 